\title{
OPEN Lupeol acetate as a potent antifungal compound against opportunistic human and phytopathogenic mold Macrophomina phaseolina
}

\author{
Shabnam Javed ${ }^{1,2,3}$, Zaid Mahmood ${ }^{1,4}$, Khalid Mohammed Khan ${ }^{2}$, Satyajit D. Sarker ${ }^{3}$, \\ Arshad Javaid ${ }^{5}$, Iqra Haider Khan ${ }^{5}$ \& Amna Shoaib $\mathbb{1}^{5 凶}$
}

Antifungal activity of Monotheca buxifolia methanolic extract and its various fractions were assessed against Macrophomina phaseolina, a soil-borne fungal pathogen of more than 500 vegetal species as well as rare and emerging opportunistic human pathogen. Different concentrations of methanolic extract ( 3.125 to $200 \mathrm{mg} \mathrm{mL}^{-1}$ ) inhibited fungal biomass by $39-45 \%$. Isolated $n$-hexane, chloroform and ethyl acetate fractions suppressed fungal biomass by $32-52 \%, 29-50 \%$ and $29-35 \%$, respectively. Triterpenes lupeol and lupeol acetate $(1,2)$ were isolated from $n$-hexane while betulin, $\beta$-sitosterol, $\beta$-amyrin, oleanolic acid (3-6) were isolated from chloroform fraction. Vanillic acid, protocatechuic acid, kaempferol and quercetin (7-10) were isolated from the ethyl acetate fraction and identified using various spectroscopic techniques namely mass spectroscopy and NMR. Antifungal activity of different concentrations $\left(0.0312\right.$ to $\left.2 \mathrm{mg} \mathrm{mL}^{-1}\right)$ of the isolated compounds was evaluated and compared with the activity of a broad spectrum fungicide mancozeb. Different concentrations of mencozeb reduced fungal biomass by $83-85 \%$. Among the isolated compounds lupeol acetate (2) was found the highest antifungal against $M$. phaseolina followed by betulin (3), vanillic acid (7), protocatechuic acid (8), $\beta$-amyrin (5) and oleanolic acid (6) resulting in 79-81\%, 77-79\%, 74-79\%, $67-72 \%, 68-71 \%$ and $68-71 \%$, respectively. Rest of the compounds also showed considerable antifungal activity and reduced $M$. phaseolina biomass by $41-64 \%$.

Macrophomina phaseolina is an important soil-borne plant pathogen that causes diseases over 500 plant species including economically important crops such as legumes, sunflower, cotton, sorghum and vegetables. Generally it causes charcoal rot disease in various crops; however, it also causes other diseases such as seedling and stem blight, damping off and wilt ${ }^{1}$. It has vast distribution in tropical and subtropical countries, however, its exposure to human may cause infection in immunosuppressed patients. Several strategies are being adopted to control fungal plant pathogens by synthetic fungicides. No doubt, these fungicides are effective in controlling plant diseases but they also pose severe hazards to human health and cause environmental pollution by accumulation in soil and water ${ }^{2}$. It necessitates alternative environmental friendly strategies for management of phytopathogens. Many recent studies have shown that crude plant extracts as well as purified compounds isolated from various plant species are very effective in the control of fungal plant pathogens $s^{3-5}$. Studies have shown that plant extracts of Chenopodium spp., Senna occidentalis and Cirsium arvense can control growth of M. phaseolina and charcoal rot of mungbean ${ }^{6-10}$. From Azadirachta and Mango leaves, three flavonoids (-)-epi-catechin, (-)-epicatechin3-O- $\beta$-glucopyranoside and 6-(phydroxybenzyl)taxifolin-7-O- $\beta$-D-glucoside were isolated and found effective against $M$. phaseolina ${ }^{11,12}$.

\footnotetext{
${ }^{1}$ Institute of Chemistry, University of the Punjab, Quaid-e-Azam Campus, Lahore, Pakistan. ${ }^{2} \mathrm{H}$. E. J. Research Institute of Chemistry, International Centre for Chemical and Biological Sciences, University of Karachi, Karachi, Pakistan. ${ }^{3}$ Centre for Natural Products Discovery, School of Pharmacy and Biomolecular Sciences, Liverpool John Moores University, James Parsons Building, Byrom Street, Liverpool L3 3AF, UK. ${ }^{4}$ Department of Chemistry and Environmental Sciences, University of Lahore, Lahore, Pakistan. ${ }^{5}$ Institute of Agricultural Sciences, University of the Punjab, Quaid-e-Azam Campus, Lahore, Pakistan. ${ }^{\circledR}$ email: amna.iags@pu.edu.pk
} 
Monotheca buxifolia (Falc.) A. DC. is monotypic genus of the family Sapotacea, grows mainly in Malakand Dir district, Pakistan. M. buxifolia is reported for wide-range of pharmacological activities including cough, wound healing, headache, analgesic, antipyretic, antiseptic and urinary tract infections ${ }^{13}$. The antibacterial activity of crude ethanolic extract and fractions of M. buxifolia using agar well diffusion technique confirmed their antibacterial potential ${ }^{14}$. Javed et al. ${ }^{15}$ isolated and identified five triterpenes from the bioactive fractions of aerial parts of M. buxifolia and displayed potent cytotoxic activities in vitro. The other plants of family Sapotaceae are widely explored and reported for significant antimycotic activities in various experimental models, but there is not only a single report on antifungal activity and isolation of antifungal compounds from M. buxifolia ${ }^{16}$. Therefore, the present investigation was conducted to explore antifungal potential of $M$. buxifolia fractions and isolated compounds against $M$. phaseolina, a highly problematic phytopathogen for which there is not any registered fungicide up to now.

\section{Results}

Characteristic of the compounds. Compound 1. EI-MS $\mathrm{m} / z$ (relative intensity): 426(52) $[\mathrm{M}]^{+}$, 411(20), 393 (8), 218(42), 207(80), 189(100), 139(74). EIMS showed fragment peaks at $m / z 411\left[\mathrm{M}^{+}-\mathrm{CH}_{3}\right], 218$ $\left[\mathrm{M}^{+}-\mathrm{C}_{14} \mathrm{H}_{20}\right], 207(80)$ which are characteristic signals for pentacyclic triterpenes having isopropenyl group. HREI-MS $m / z$ : 426.3820 (calcd. for $\mathrm{C}_{30} \mathrm{H}_{50} \mathrm{O}, 426.3862$ ). The ${ }^{1} \mathrm{H}-\mathrm{NMR}$ spectrum of 24 showed seven singlet for methyl protons at $\delta 0.74,0.81,0.85,0.89,0.91,0.97$ and 1.06 signals, one for each of seven methyl protons. A pair of multiplets at $\delta 4.20$ and 4.21 , each for $\mathrm{H}-29$, identified the presence of terminal isopropenyl group, characteristic of lupane series of triterpenoids. ${ }^{13} \mathrm{C}$ NMR spectrum showed 30 signals for the triterpenoid lupane skeleton, including C-3 at $\delta 79.2$ bonded to the hydroxyl group. Compound 1 was identified as Lupeol ${ }^{19}$.

Compound 2. HREI-MS showed $[\mathrm{M}]^{+} 468.3967$ correlated with $\mathrm{C}_{32} \mathrm{H}_{52} \mathrm{O}_{2}$. EI-MS showed fragments 427 $\left[\mathrm{M}^{+}-41\right], 408\left[\mathrm{M}^{+}-\mathrm{AcOH}\right], 249\left[\mathrm{M}^{+}-\mathrm{C}_{16} \mathrm{H}_{27}\right]$ and $189\left[\mathrm{M}^{+}-\mathrm{C}_{16} \mathrm{H}_{27}-\mathrm{AcOH}\right] .{ }^{1} \mathrm{H}-\mathrm{NMR}$ spectrum of 2 recorded seven tertiary methyl group at $\delta 0.76,0.81,0.83,0.86,0.92,1.01,1.31$ and methyl acetate at 2.32 . A pair of broad singlets at $\delta 4.47$ and 4.44 showed presence of exomethylene group. A double doublet at $\delta 4.03, J=9.8,4.3 \mathrm{~Hz}$ was due to C-3 proton, bonded to acetoxy group. The coupling constant along with chemical shift describes the absolute configuration of acetoxy group, $\beta$ and equatorial at C-3. The recorded data of 2 is comparable with the data reported for lupeol acetate in the literature ${ }^{20}$.

Compound 3. HR-EI-MS spectrum showed $[\mathrm{M}]^{+}$at 442.3819 deduced for molecular formula $\mathrm{C}_{30} \mathrm{H}_{50} \mathrm{O}_{2}$ depicted six degrees of unsaturation. ${ }^{1} \mathrm{H}-\mathrm{NMR}$ spectrum showed $\delta$ at $3.25(d d, J, 11.4,5.2 \mathrm{~Hz})$ was attributed due to $\mathrm{H}-3$ germinal to $-\mathrm{OH}$ proton. Two broad singlets appeared at $\delta 4.46$ and 4.92 (br s, $1 \mathrm{H}$ each) were assigned to terminal isopropenyl group. Six tertiary methyl singlets were observed at $\delta(0.86,0.83,0.84,0.87,1.02,1.04)$ were assumed for methyl protons of $(\mathrm{H}-23, \mathrm{H}-24, \mathrm{H}-25, \mathrm{H}-26, \mathrm{H}-27$ and $\mathrm{H}-30)$. One doublet appeared at $\delta 3.40$ and $3.71(2 \mathrm{H}, d, J=11.2 \mathrm{~Hz})$ was due to methylene protons of C-28. Compound 3 can be identified as Betulin ${ }^{21}$.

Compound 4. HR-EI-MS spectrum showed $[\mathrm{M}]^{+}$at 414.3838 , correlated with molecular formula $\mathrm{C}_{29} \mathrm{H}_{50} \mathrm{O}$ (calcd. $\mathrm{m} / z$ : 414.3661). Characetristic fragment ions $\mathrm{m} / z 414$ and 396 in EI-MS spectrum also confirmed $\beta$-sitosterol pattern. Similarly fragment ion $\mathrm{m} / z 255$ was recorded due to loss of $\left[\mathrm{M}^{+}\right.$-side chain- $\left.\mathrm{H}_{2} \mathrm{O}\right]$ and fragments $m / z: 329,303$ confirmed the diagnostic pattern for sterols with $\Delta^{5}$-unsaturation. The ${ }^{1} \mathrm{H}$-NMR spectrum also confirmed the characteristic steroid pattern, one triplet at $\delta 5.41(J=3.2 \mathrm{~Hz})$ was assigned for olefinic proton of C-6 and a carbinylic signal was recorded at $\delta 3.45(1 \mathrm{H}, m)$. Some doublet signals appeared at $\delta 0.902(J=6.4)$, $0.86(J=6.6), 0.82(J=6.6), 0.89(J=6.8)$ and were recommended for C-21, 26, 27 and C-29 methyl protons. The ${ }^{13} \mathrm{C}$-NMR spectrum of compound 4 showed 29 carbons with 6 methyl, 11 methylene, 9 methine and 3 quaternary carbon atoms. The compound 4 was identified as $\beta$-sitosterol, also confirmed by reported data in literature ${ }^{22}$.

Compound 5. HR-EI-MS showed $\mathrm{M}]^{+}$at $m / z$ 426.3534, established molecular formula $\mathrm{C}_{30} \mathrm{H}_{50} \mathrm{O}$, calculated by 426.3860. Eight tertiary methyl protons were identified in the ${ }^{1} \mathrm{H}$ NMR spectrum $\left(500 \mathrm{MHz}, \mathrm{CD}_{3} \mathrm{OD}\right) \delta 0.80$, $0.84,0.88,0.95,1.12,1.34,1.01$ and 1.11 , each $(3 \mathrm{H}, s)$. C- 12 olefinic proton was also indicated at $\delta 5.22(1 \mathrm{H}, b r$, $s)$ and a double doublet at $\delta 3.61(1 \mathrm{H}, d d, J=8,4.4 \mathrm{~Hz})$ was due to $\mathrm{C}-3$ proton. The ${ }^{13} \mathrm{C}$ NMR (BB and DEPT) spectrum showed presence of $8-\mathrm{CH}_{3}, 10-\mathrm{CH}_{2}, 5-\mathrm{CH}$ and 7 -quaternary carbons. The spectroscopic data was identical with the data of well-known compound reported in the literature, commonly known as $\beta$-amyrin ${ }^{23}$.

Compound 6. HR-EI-MS spectrum showed the $[\mathrm{M}]^{+}$at $m / z$ 456. 3671 recommended for $\mathrm{C}_{30} \mathrm{H}_{48} \mathrm{O}_{3}$ calculated for 456.3603. EI-MS spectrum in addition to recording molecular ion peak $\mathrm{m} / z 456$ showed characteristic fragment ions $m / z 248,203$ and 133 for $\Delta^{12}$ amyrin skeleton. The ${ }^{1} \mathrm{H}$ NMR spectrum displayed the signal for olefininc proton at $\delta 5.18(1 \mathrm{H}, b r s, \mathrm{H}-12)$ and oxymethine proton germinal to hydroxyl group at $\delta 3.14(1 \mathrm{H}, d d, J=10$, $5.5 \mathrm{~Hz})$. Seven singlets were also showed for seven methyl group protons were recorded at $\delta(1.19,1.02,0.92$, $0.88,0.80,0.74$ and 0.71$).{ }^{13} \mathrm{C}$ NMR spectrum showed 30 carbon signals comprising of $7-\mathrm{CH}_{3}, 10-\mathrm{CH}_{2}, 5-\mathrm{CH}$ and $8-\mathrm{C}$ carbon atoms. Carbonyl carbon showed prominent signal at $\delta 180.8$, olefinic carbons $\delta 124.4$ and oxymethine carbon $\delta$ 78.2. The above spectral data for compound $\mathbf{6}$ was in complete agreement Oleanolic acid ${ }^{24}$.

Compound 7. HREI-MS spectrum showed $[\mathrm{M}]^{+}$at 168.1124 (calculated 168.1120) for $\mathrm{C}_{8} \mathrm{H}_{8} \mathrm{O}_{4}$. In EI-MS spectra base peak $[\mathrm{M}]^{+}$is represented at 168 and other peaks at 151 and 137 represent the loss of $-\mathrm{OH}$ and $-\mathrm{OCH}_{3}$ groups. ${ }^{1} \mathrm{H}-\mathrm{NMR}$ spectrum $\left(500 \mathrm{MHz}, \mathrm{CD}_{3} \mathrm{OD}\right)$ of compound 7 presented a doublets at $\delta 6.80(J=8.2)$ and a $d d$ at 7.55 with $(J=8.2$ and $1.6 \mathrm{~Hz})$ were assigned C-5 and C-6 protons. One proton doublet at $\delta 7.60$ with 
$(J=1.6 \mathrm{~Hz}$ ), was assigned as C-2 proton. Singlet, three proton signal at $\delta 3.88$ was attributed due to three protons of methoxy group. Another singlet at $\delta 4.59$ was assigned to hydrogen of hydroxyl group. Compound 7 was thus identified as (4-hydroxy-3,5-dimethoxy benzoic acid) commonly known as vanillic acid. The ${ }^{1} \mathrm{H}$ and ${ }^{13} \mathrm{C} \mathrm{NMR}$ spectroscopic data was also verified with the previous reported data for vanillic acid ${ }^{25}$.

Compound 8. ${ }^{1} \mathrm{H}-\mathrm{NMR}$ spectrum of compound $\mathbf{8}$ showed presence of three aromatic hydrogens, which gives information that three positions of benzene ring might be substituted. Compound $\mathbf{8}$ gave one double doublet at $\delta 7.45$ with $(J=8.2,1.8 \mathrm{~Hz})$ was assigned to C-6 proton due to possibility of ortho coupling with C-5 proton and meta coupling with C-2 proton. Two doublets appeared for single protons in aromatic region can be assigned to C-5 proton with $(J=8.2 \mathrm{~Hz})$ due to ortho coupling with C-6 proton and to C-2 proton with $(J=1.8 \mathrm{~Hz})$ due to meta coupling with C-6 proton respectively. H-decoupled ${ }^{13} \mathrm{C}-\mathrm{NMR}$ spectrum, seven peaks appeared for six non-equivalent carbons and one carboxylic carbon. The calculated mass for compound 18 with molecular formula $\mathrm{C}_{7} \mathrm{H}_{6} \mathrm{O}_{4}$ was 154.2338 and 154.2331 was observed again confirms the compound as protocatechuic acid ${ }^{26}$.

Compound 9. Molecular ion peak $[\mathrm{M}]^{+}$was recorded at 286.0475 which is compatible for molecular formula $\mathrm{C}_{15} \mathrm{H}_{10} \mathrm{O}_{6}$. EI-MS showed characteristic fragments at 257, 229, 213, 121,104, 93, 77 and 69. ${ }^{1} \mathrm{H}$ NMR spectrum displayed two doublets at $\delta 8.03$ and $\delta 6.92$ representing AA'BB' pattern for para-substituted benzene. Two meta coupled doublets also appeared at $\delta 6.42$ and 6.18 with $J=1.8 \mathrm{~Hz}$. Characteristic flavonoid signals 137.2, 146.2 were shown clearly in ${ }^{13} \mathrm{C}$ NMR (DEPT and BB) spectra. ${ }^{13} \mathrm{C}$ NMR signals at $\delta 161.4,160.2$ and 114.2 represent the para-substituted benzene ring moiety. Similarly carbon atoms directly linked with oxygen displayed signals at 161.4, 103.4 and 160.2. The spectroscopic data was also matched with the reported data in literature and compound (9) was identified as 3,4',5,7-tetrahydroxyflavone commonly known as kaempferol ${ }^{27}$.

Compound 10. Compound (10) HR-EI-MS spectra depicted molecular ion peak at $\mathrm{m} / z 302.0285$ with relevant molecular formula $\mathrm{C}_{15} \mathrm{H}_{10} \mathrm{O}_{6}$. The ${ }^{1} \mathrm{H}$-NMR spectrum of (10) showed five signals each for five different aromatic protons. A doublet signal at 7.72 represents single proton in meta coupling with $\mathrm{H}-6^{\prime}, 2.1 \mathrm{~Hz}$ might be attributed due to $\mathrm{H}-2^{\prime}$. A double doublet at 7.62 represents $\mathrm{H}-6^{\prime}$, in meta coupling with $\mathrm{H}-2^{\prime}, J=2.1 \mathrm{~Hz}$ and ortho coupling with $\mathrm{H}-5^{\prime}, J=8.4 \mathrm{~Hz}$. Another doublet at 6.87 might be due to $\mathrm{H}-5^{\prime}, J=8.4$. It suggested an $\mathrm{ABC}$ type-system having flavonol moiety with $3^{\prime}, 4^{\prime}$-disubstituted B-ring. Similarly a pair of meta coupling protons signals at $6.17(1 \mathrm{H}, d, J=1.8, \mathrm{H}-6)$ and $6.38(1 \mathrm{H}, d, J=1.8, \mathrm{H}-8)$ were recorded for ring $\mathrm{A} .{ }^{13} \mathrm{C}-\mathrm{NMR}$ spectra showed 15 signals having carbonyl signal at $\delta 170.5$ for $\mathrm{C}-4$. Five carbon nuclei attached to hydroxyl group gave five signals recorded at $\delta \mathrm{C} 137.1$ (C-3), 160.9 (C-5), 165.1 (C-7), $146.4\left(\mathrm{C}-3^{\prime}\right), 150.8$ (C-4') also supported the presence of $3,5,7,3^{\prime}, 4^{\prime}$-oxygenated flavone nucleus. The detailed studies on compound $\mathbf{1 0}$ were in consistent with the reported spectroscopic data, commonly known as quercetin ${ }^{28}$.

Antifungal activity of fractions and isolated compounds. Different concentrations of methanolic extract suppressed fungal biomass by $34-49 \%$. Likewise, there was $31-52 \%, 29-50 \%, 17-36 \%$ and $34-48 \%$ reduction in biomass of $M$. phaseolina due to different concentrations of methanolic $n$-hexane, chloroform, ethyl acetate and aqueous fraction of methanolic leaf extract, respectively (Fig. 1).

Antifungal activity of mencozeb and the ten isolated compounds against M. phaseolina is shown in Table 1. Fungicide mencozeb showed the highest antifungal activity causing $83-84 \%$ reduction in fungal biomass. In general, all the isolated compounds suppressed fungal growth variably and significantly. Out of the isolated compounds, lupeol acetate (2) showed the highest antifungal against M. phaseolina, causing 79-81\% followed by betulin (3) 77-79\% reduction in biomas of the target fungus, respectively. Other compounds showing pronounced antifungal activities were $\beta$-amyrin (5), oleanolic acid (6), vanillic acid (7) and protocatechuic acid (8) that reduced fungal biomass by $68-71 \%, 68-71 \%, 74-79 \%$ and $67-72 \%$, respectively. Compounds namely lupeol (1), $\beta$-sitosterol (4), kaempferol (9) and quercetin (10) were comparatively less antifungal and reduced fungal biomass by $40-43 \%, 57-64 \%, 46-53 \%$ and $47-55 \%$, respectively over corresponding control.

\section{Discussion}

Identification of isolated compounds. From M. buxifolia methanolic extract ten compounds were isolated from various sub-fractions. Various physical analysis and spectroscopic data co-ordinated from the already reported data and compound $\mathbf{1}$ was identified as lupeol, compound $\mathbf{2}$ as lupeol acetate, compound $\mathbf{3}$ as betulin, compound 4 as $\beta$-sitosterol, compound 5 as $\beta$-amyrin, compound $\mathbf{6}$ as oleanolic acid, compound 7 as vanillic acid, compound $\mathbf{8}$ as protocatechuic acid, compound $\mathbf{9}$ as kaempferol and compound $\mathbf{1 0}$ as quercetin ${ }^{19-28}$ Struc- $^{-}$ tures of these compounds are presented in Fig. 2.

Antifungal potential of fractions and isolated compounds. All the concentrations of methanolic extracts and its various fractions significantly reduced fungal biomass. Antifungal activity of both compounds lupeol acetate (2) 79-81\% and betulin (3) 77-79\% were found very close to that of fungicide mancozeb $83-84 \%$. Some earlier studies also reported antifungal activity of lupeol acetate (2) against Aspergillus flavus. However, most of the previous studies showed antibacterial activity of this compound against Bacillus subtilis, Staphylococcus aureus and Escherichia coli ${ }^{29,30}$. In contrast to the present study, Manzano et al. ${ }^{31}$ reported no antifungal activity of 2 against Penicillium chrysogenum and Fusarium oxysporum, showing specificity of this compound against $M$. phaseolina. Betulin (3) has been reported fungicidal against a number of fungi including Fusarium solani and Aspergillus niger and its effect was equal to standard antifungal drug miconazole ${ }^{32}$. 


\section{Control 㖆 Experimental}

\section{Methanolic Extract}

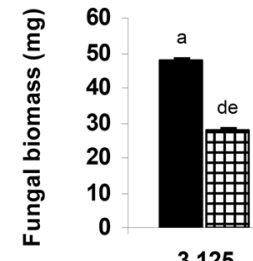

3.125
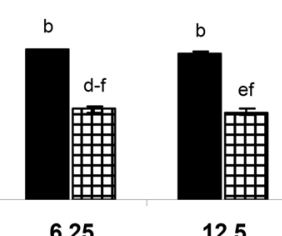

12.5

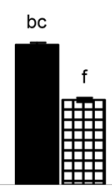

25

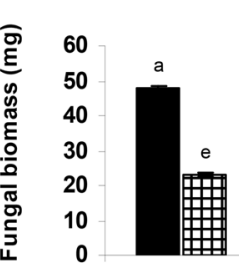

3.125

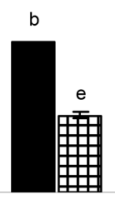

6.25

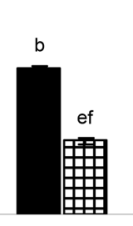

12.5

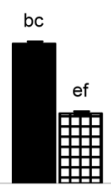

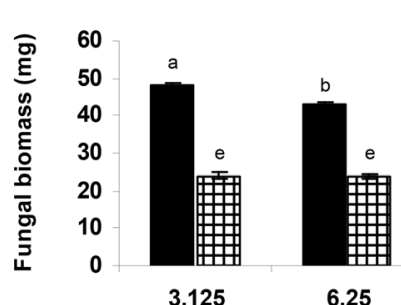

Chloroform Fraction

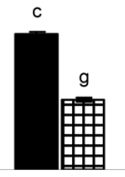

50
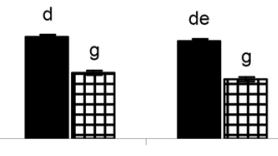

100

200

$\mathrm{HSD}_{0.05}=\mathbf{3 . 2 6}$

B

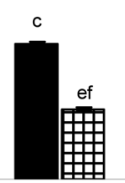

50
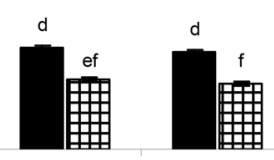

100

200<smiles>[AsH]=[AsH]=[SbH2]</smiles>
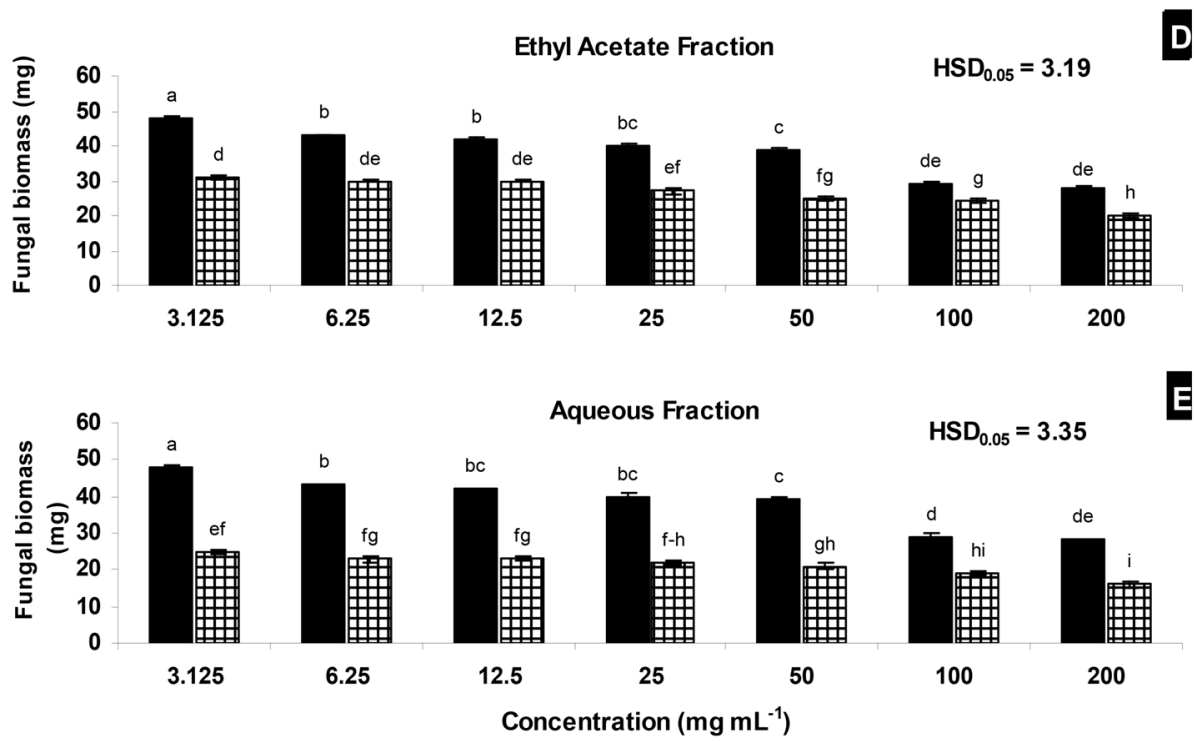

Figure 1. (A-E) Effect of methanolic extract of Monotheca buxifolia and its fractions on biomass of Macrophomina phaseolina. Vertical bars show standard errors of means of three replicates. Values with different letters at their top show significant difference $(\mathrm{P} \leq 0.05)$ as determined by Tukey's HSD test.

$\beta$-Amyrin (5) is known to inhibit growth of various clinical fungal species namely Candida stellatoidea, Candida krusei, Microsporum sp. and Trichophyton rubrum and Ascochyta rabiei, the cause of blight disease of chickpea $^{33,34}$ Oleanolic acid (6) is a pentacyclic triterpenoid that is widely spread in plant kingdom, with members of Oleaceae family as its main source. Apart from its various pharmaceutical properties, it also possesses antifungal activity against yeast and dermatophyte species ${ }^{35,36}$. Protocatechuic acid (8) is a type of phenolic acid that is found in many food plants and possesses a number of pharmaceutical properties and antifungal activity against Microsporum audouinii ${ }^{37,38}$. 


\begin{tabular}{|c|c|c|c|c|}
\hline $\begin{array}{l}\text { Methanolic extract } \\
\text { fraction }\end{array}$ & Conc. of DMSO $\left(\mu \mathrm{L} \mathrm{mL}^{-1}\right)$ & $\begin{array}{l}\text { Compound conc (mg } \\
\mathrm{mL}^{-1} \text { ) }\end{array}$ & Fungal biomass (mg) & Decrease over control (\%) \\
\hline \multirow{7}{*}{ Control } & 0.104 & 0.0000 & $23.4 \mathrm{~A}$ & - \\
\hline & 0.208 & 0.0000 & $22.6 \mathrm{AB}$ & - \\
\hline & 0.416 & 0.0000 & $22.8 \mathrm{AB}$ & - \\
\hline & 0.832 & 0.0000 & $21.1 \mathrm{BC}$ & - \\
\hline & 1.66 & 0.0000 & $21.3 \mathrm{~B}$ & - \\
\hline & 3.33 & 0.0000 & $21.0 \mathrm{BC}$ & - \\
\hline & 6.66 & 0.0000 & $19.2 \mathrm{C}$ & - \\
\hline \multirow{7}{*}{ Mencozeb } & 0.104 & 0.0312 & $3.9 \mathrm{Za}-\mathrm{e}$ & 83 \\
\hline & 0.208 & 0.0625 & $3.7 \mathrm{a}-\mathrm{e}$ & 84 \\
\hline & 0.416 & 0.1250 & $3.8 \mathrm{a}-\mathrm{e}$ & 83 \\
\hline & 0.832 & 0.2500 & $3.5 \mathrm{~d}-\mathrm{e}$ & 83 \\
\hline & 1.66 & 0.5000 & $3.5 \mathrm{~b}-\mathrm{e}$ & 83 \\
\hline & 3.33 & 1.0000 & $3.3 \mathrm{c}-\mathrm{e}$ & 85 \\
\hline & 6.66 & 2.0000 & $3.1 \mathrm{e}$ & 84 \\
\hline \multirow{7}{*}{ Lupeol (1) } & 0.104 & 0.0312 & $13.3 \mathrm{DE}$ & 43 \\
\hline & 0.208 & 0.0625 & $13.4 \mathrm{D}$ & 41 \\
\hline & 0.416 & 0.1250 & $13.4 \mathrm{D}$ & 41 \\
\hline & 0.832 & 0.2500 & $12.8 \mathrm{D}-\mathrm{F}$ & 39 \\
\hline & 1.66 & 0.5000 & $12.3 \mathrm{D}-\mathrm{G}$ & 42 \\
\hline & 3.33 & 1.0000 & $12.5 \mathrm{D}-\mathrm{G}$ & 40 \\
\hline & 6.66 & 2.0000 & $11.6 \mathrm{D}-\mathrm{H}$ & 40 \\
\hline \multirow{7}{*}{ Lupeol acetate (2) } & 0.104 & 0.0312 & $4.6 \mathrm{~T}-\mathrm{Za}-\mathrm{e}$ & 80 \\
\hline & 0.208 & 0.0625 & $4.6 \mathrm{~T}-\mathrm{Za}-\mathrm{e}$ & 80 \\
\hline & 0.416 & 0.1250 & $4.3 \mathrm{~V}-\mathrm{Za}-\mathrm{e}$ & 81 \\
\hline & 0.832 & 0.2500 & $4.3 \mathrm{~V}-\mathrm{Za}-\mathrm{e}$ & 80 \\
\hline & 1.66 & 0.5000 & $4.0 \mathrm{Y}-\mathrm{Za}-\mathrm{e}$ & 81 \\
\hline & 3.33 & 1.0000 & $3.9 \mathrm{Za}-\mathrm{e}$ & 81 \\
\hline & 6.66 & 2.0000 & $4.0 \mathrm{Y}-\mathrm{Za}-\mathrm{e}$ & 79 \\
\hline \multirow{7}{*}{ Betulin (3) } & 0.104 & 0.0312 & $5.7 \mathrm{O}-\mathrm{Za}$ & 76 \\
\hline & 0.208 & 0.0625 & $5.3 \mathrm{P}-\mathrm{Za}-\mathrm{c}$ & 77 \\
\hline & 0.416 & 0.1250 & $5.2 \mathrm{P}-\mathrm{Za}-\mathrm{d}$ & 77 \\
\hline & 0.832 & 0.2500 & $4.5 \mathrm{U}-\mathrm{Za}-\mathrm{e}$ & 79 \\
\hline & 1.66 & 0.5000 & $4.7 \mathrm{~S}-\mathrm{Za}-\mathrm{e}$ & 78 \\
\hline & 3.33 & 1.0000 & $4.5 \mathrm{U}-\mathrm{Za}-\mathrm{e}$ & 79 \\
\hline & 6.66 & 2.0000 & $4.2 \mathrm{X}-\mathrm{Za}-\mathrm{e}$ & 78 \\
\hline \multirow{7}{*}{$\beta$-Sitosterol (4) } & 0.104 & 0.0312 & $9.4 \mathrm{I}-\mathrm{K}$ & 60 \\
\hline & 0.208 & 0.0625 & $9.4 \mathrm{I}-\mathrm{K}$ & 58 \\
\hline & 0.416 & 0.1250 & $9.0 \mathrm{~J}-\mathrm{L}$ & 61 \\
\hline & 0.832 & 0.2500 & $9.1 \mathrm{~J}-\mathrm{L}$ & 57 \\
\hline & 1.66 & 0.5000 & $8.0 \mathrm{~K}-\mathrm{M}$ & 62 \\
\hline & 3.33 & 1.0000 & $7.7 \mathrm{~K}-\mathrm{N}$ & 64 \\
\hline & 6.66 & 2.0000 & $7.7 \mathrm{~K}-\mathrm{N}$ & 60 \\
\hline \multirow{7}{*}{$\beta$-Amyrin (5) } & 0.104 & 0.0312 & $7.4 \mathrm{~L}-\mathrm{O}$ & 68 \\
\hline & 0.208 & 0.0625 & $6.9 \mathrm{M}-\mathrm{Q}$ & 69 \\
\hline & 0.416 & 0.1250 & $6.5 \mathrm{M}-\mathrm{U}$ & 71 \\
\hline & 0.832 & 0.2500 & $6.6 \mathrm{M}-\mathrm{T}$ & 69 \\
\hline & 1.66 & 0.5000 & $6.6 \mathrm{M}-\mathrm{T}$ & 69 \\
\hline & 3.33 & \begin{tabular}{|l|}
1.0000 \\
\end{tabular} & $6.2 \mathrm{M}-\mathrm{X}$ & 70 \\
\hline & 6.66 & 2.0000 & $6.2 \mathrm{M}-\mathrm{X}$ & 68 \\
\hline \multirow{7}{*}{ Oleanolic acid (6) } & 0.104 & 0.0312 & $6.8 \mathrm{M}-\mathrm{R}$ & 71 \\
\hline & 0.208 & 0.0625 & $6.7 \mathrm{M}-\mathrm{S}$ & 70 \\
\hline & 0.416 & 0.1250 & $6.7 \mathrm{M}-\mathrm{S}$ & 71 \\
\hline & 0.832 & 0.2500 & $6.3 \mathrm{M}-\mathrm{V}$ & 70 \\
\hline & 1.66 & 0.5000 & $6.5 \mathrm{M}-\mathrm{U}$ & 69 \\
\hline & 3.33 & 1.0000 & $6.3 \mathrm{M}-\mathrm{V}$ & 70 \\
\hline & 6.66 & 2.0000 & $6.0 \mathrm{~N}-\mathrm{Y}$ & 68 \\
\hline
\end{tabular}




\begin{tabular}{|c|c|c|c|c|}
\hline $\begin{array}{l}\text { Methanolic extract } \\
\text { fraction }\end{array}$ & Conc. of DMSO $\left(\mu \mathrm{L} \mathrm{mL}^{-1}\right)$ & $\begin{array}{l}\text { Compound conc (mg } \\
\mathrm{mL}^{-1} \text { ) }\end{array}$ & Fungal biomass (mg) & Decrease over control (\%) \\
\hline \multirow{7}{*}{ Vanillic acid (7) } & 0.104 & 0.0312 & $6.2 \mathrm{M}-\mathrm{X}$ & 74 \\
\hline & 0.208 & 0.0625 & $5.6 \mathrm{O}-\mathrm{Za}$ & 76 \\
\hline & 0.416 & 0.1250 & $5.6 \mathrm{O}-\mathrm{Za}$ & 79 \\
\hline & 0.832 & 0.2500 & $5.4 \mathrm{O}-\mathrm{Zab}$ & 74 \\
\hline & 1.66 & 0.5000 & $4.7 \mathrm{~S}-\mathrm{Za}-\mathrm{e}$ & 78 \\
\hline & 3.33 & 1.0000 & $4.9 \mathrm{R}-\mathrm{Za}-\mathrm{e}$ & 77 \\
\hline & 6.66 & 2.0000 & $4.9 \mathrm{R}-\mathrm{Za}-\mathrm{e}$ & 74 \\
\hline \multirow{7}{*}{ Protocatechuic acid (8) } & 0.104 & 0.0312 & $6.9 \mathrm{M}-\mathrm{Q}$ & 71 \\
\hline & 0.208 & 0.0625 & $6.7 \mathrm{M}-\mathrm{S}$ & 70 \\
\hline & 0.416 & 0.1250 & $6.9 \mathrm{M}-\mathrm{Q}$ & 70 \\
\hline & 0.832 & 0.2500 & $6.9 \mathrm{M}-\mathrm{Q}$ & 67 \\
\hline & 1.66 & 0.5000 & $6.5 \mathrm{M}-\mathrm{U}$ & 72 \\
\hline & 3.33 & 1.0000 & $6.2 \mathrm{M}-\mathrm{X}$ & 70 \\
\hline & 6.66 & 2.0000 & $5.9 \mathrm{~N}-\mathrm{Z}$ & 69 \\
\hline \multirow{7}{*}{ Kaempferol (9) } & 0.104 & 0.0312 & $12.3 \mathrm{D}-\mathrm{G}$ & 50 \\
\hline & 0.208 & 0.0625 & $11.6 \mathrm{D}-\mathrm{H}$ & 50 \\
\hline & 0.416 & 0.1250 & $11.3 \mathrm{E}-\mathrm{I}$ & 50 \\
\hline & 0.832 & 0.2500 & $11.3 \mathrm{E}-\mathrm{I}$ & 46 \\
\hline & 1.66 & 0.5000 & $10.8 \mathrm{G}-\mathrm{J}$ & 58 \\
\hline & 3.33 & 1.0000 & $9.0 \mathrm{~J}-\mathrm{L}$ & 57 \\
\hline & 6.66 & 2.0000 & $9.1 \mathrm{~J}-\mathrm{L}$ & 53 \\
\hline \multirow{8}{*}{ Quercetin (10) } & 0.104 & 0.0312 & $12.0 \mathrm{D}-\mathrm{H}$ & 49 \\
\hline & 0.208 & 0.0625 & $12.0 \mathrm{D}-\mathrm{H}$ & 47 \\
\hline & 0.416 & 0.1250 & $11.8 \mathrm{D}-\mathrm{H}$ & 48 \\
\hline & 0.832 & 0.2500 & $11.2 \mathrm{~F}-\mathrm{I}$ & 47 \\
\hline & 1.66 & 0.5000 & $10.1 \mathrm{H}-\mathrm{J}$ & 53 \\
\hline & 3.33 & 1.0000 & $9.5 \mathrm{I}-\mathrm{K}$ & 55 \\
\hline & 6.66 & 2.0000 & $9.0 \mathrm{~J}-\mathrm{L}$ & 53 \\
\hline & \multicolumn{2}{|l|}{$\mathrm{HSD}_{0.001}$} & 2.01 & \\
\hline
\end{tabular}

Table 1. Effect of different concentrations of fungicide mancozeb and compounds isolated from Monotheca buxifolia on growth appearance and biomass of Macrophomina phaseolina. Values with different letters in a column show significant difference $(\mathrm{P} \leq 0.001)$ as determined by Tukey's HSD test.

Lupeol (1), a pentacyclic triterpenoid, has also been isolated from a number of plant species including green pepper, mangoes, strawberry, grapes, white cabbage and olive, and is known to have useful effect as a preventive and therapeutic agent against a number of ailments ${ }^{39}$. Although in the present study, it found comparatively less effective against $M$. phaseolina, however, it was highly effective against Penicillium notatum causing $90 \%$ growth inhibition when used in $200 \mu \mathrm{g} \mathrm{mL}^{-1}$ concentration $^{31}$. It was also inhibitory to the growth of Fusarium solani, Aspergillus niger, Rhizoctoia phaseoli, Candida albicans, Penicillium chrysogenum, Cantharellus flavus and Microsporum canis, and its antifungal activity was comparable with miconazole ${ }^{40}$. $\beta$-Sitosterol (4) is known to inhibit growth of Aspergillus niger and Cladosporium cladosporioides at a concentration of $0.01 \mathrm{mg} \mathrm{mL}^{-1}$. It also inhibited growth of germ tube of Fusarium verticillioides by $82 \%$ at $50 \mathrm{mg} \mathrm{mL}^{-141}$. Quercetin (10) is a polyphenolic flavonoid and showed a low activity against different Candida species ${ }^{42}$. This compound is also known to increase efficacy of a fungicidal compound amphotericin B against a clinical fungal species Cryptococcus neoformans ${ }^{43}$. Kaempferol (9) is a phenolic compounds generally showing antibacterial activity ${ }^{44}$. Information regarding its antifungal activity are very rare. The present study concludes that aerial parts of $M$. buxifolia contain potentent antifungal constituents especially lupeol acetate (2) causing 79-81\% reduction followed by betulin (3) 77-79\% and vanillic acid (7) 74-79\% for the management of $M$. phaseolina, a highly problematic phytopathogen for which there is not any registered fungicides so far.

\section{Materials and methods}

Chemicals and reagents. Chemicals were attained from Sigma-Aldrich Germany. For isolation work including chromatography various solvents were acquired from Fischer Scientific (Loughborough, UK). Silica and Flash column silica (70-230 mesh) and (230-400 mesh) were assimilated from E. Merck, Darmstadt, Germany. 


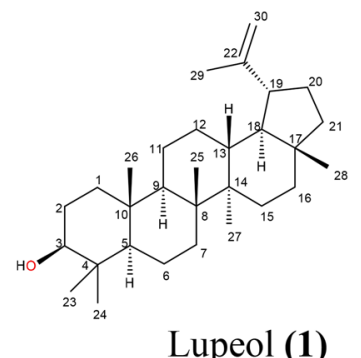

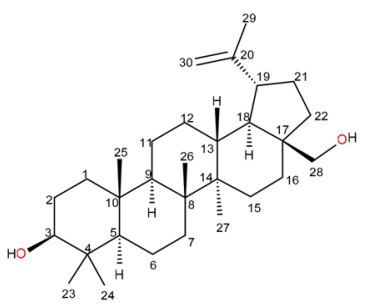

Betulin (3)

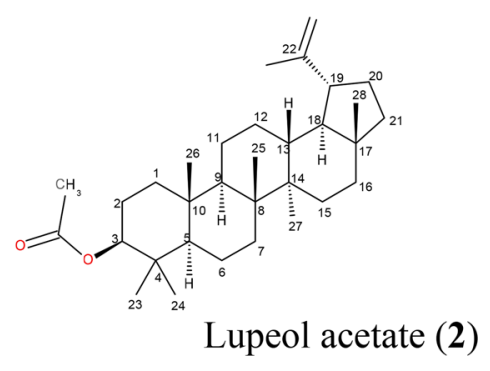

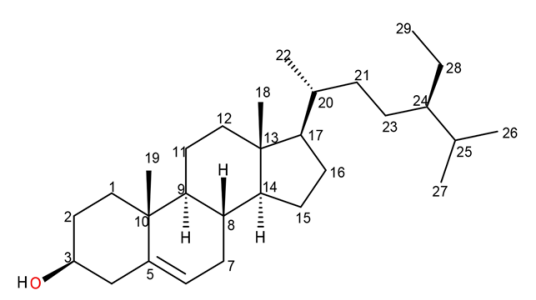

$\beta$-sitosterol (4)

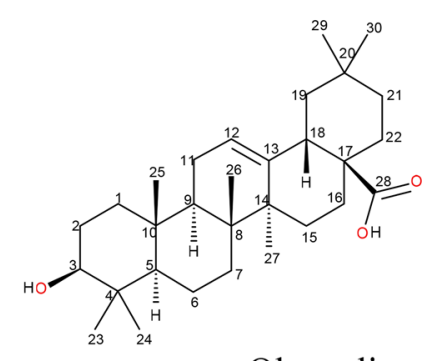

Oleanolic acid (6)<smiles>COc1cc(C(=O)O)ccc1O</smiles>

Vanillic acid (7)<smiles>O=C1c2c(O)cc(O)cc2OC(c2ccc(I)cc2)C1O</smiles>

Kaempferol (9)<smiles>O=C(O)c1ccc(O)c(O)c1</smiles>

Protocatechuic acid (8)<smiles></smiles>

Quercetin (10)

Figure 2. Structures of compounds isolated from $n$-hexane (1 and 2), chloroform (3-6) and ethyl acetate (7-10) fraction of methanolic extract of Monotheca buxifolia.

Physical parameters and spectroscopic analysis. Melting point apparatus Buchi 535 was used to record melting point. Digital Polarimeter; Jasco DIP-360 was used to record optical rotation. Shimadzu UV-240 spectrophotometer was used to record $\lambda_{\max }$ in $\mathrm{nm}$. Infrared spectra (IR) were recorded on Shimadzu IR-460 in nujol or $\mathrm{KBr}$ pellets and reported in $\mathrm{cm}^{-1}$. NMR spectra were recorded on Bruker AMX-500 and AM-400 for ${ }^{1} \mathrm{H}$ $(300-500 \mathrm{MHz})$ and ${ }^{13} \mathrm{C}(125-150 \mathrm{MHz})$ spectrometers. "spectra were recorded on Bruker Avance spectrometers ranging from 7.05 up to $14.09 \mathrm{~T}$ ". Mass spectrometer Jeol-JMS H X-110 was employed to record high resolution electron ionization mass spectra (HR-EIMS). 
Collection, extraction and fractionation from plant material. M. buxifolia is wild and commonly grown plant species in mountains of Swat, Pakistan. Aerial parts viz., stem and leaves $(11 \mathrm{~kg})$ of M. buxifolia were collected from Swat, Pakistan according to prescribed rules in The Pakistan Trade Control of Wild Fauna and Flora Act, 2012. Species was identified by Dr. Arshad Javaid (Associate Professor, Institute of Agricultural Sciences, University of the Punjab, Lahore, Pakistan), assigned voucher no. GC. Bot. Herb. 815 (Monotheca buxifolia) and was deposited in the Dr. Sultan Ahmed Herbarium, Department of Botany, GC University, Lahore, Pakistan.

Aerial parts were dried under shade, pulverized and weighed $(4.5 \mathrm{~kg})$. Powdered plant material was soaked in $\mathrm{MeOH} 95 \%(16 \mathrm{~L} \times 4)$. Extracts were assembled and methanol was removed under reduced pressure at $50{ }^{\circ} \mathrm{C}$ temperature. Gummy mass (586 g) having dark brown colour was collected. This $\mathrm{MeOH}$ extract was added in water $(410 \mathrm{~mL})$ and further fractionation was done using $n$-hexane, chloroform and ethyl acetate $(10 \times 3 \mathrm{~L})$ each to afford 151, 102 and $152 \mathrm{~g}$ of the fractions respectively. Aqueous fraction was collected $161 \mathrm{~g}$ and all the portions were refrigerated $^{17}$.

Isolation of Macrophomina phaseolina. Diseased root pieces of mungbean were collected, washed and cut into small pieces of $0.5 \mathrm{~cm}$. Root pieces were surface sterilized using $0.1 \%$ sodium hypochlorite solution, transferred aseptically on autoclaved malt extract agar plates and incubated for 7 days at $27^{\circ} \mathrm{C}$. Grey fungal colonies appeared on root pieces which became darken with time. The colonies were further purified by growing on fresh malt extract agar plates. The fungus was isolated and identified as M. phaseolina (FCBP-0751) on the basis of characteristic black-colored oblong microsclerotia ${ }^{18}$.

Antifungal bioassays with $\boldsymbol{M}$. buxifolia extract/fractions. The methanolic extract and its four fractions were tested against the pathogenic fungus $M$. phaseolina in vitro. An amount of $1.2 \mathrm{~g}$ of methanolic extract and its various fractions was dissolved in $1 \mathrm{~mL}$ of dimethyl sulphoxide (DMSO) and added to $5 \mathrm{~mL}$ autoclaved malt extract broth to make stock solution of $200 \mathrm{mg} \mathrm{mL}^{-1}$ concentration. Six lower concentrations viz. 100, $50,25,12.5,6.25$ and $3.125 \mathrm{mg} \mathrm{mL}^{-1}$ were prepared from stock solution in series of double dilution. Similarly, control with respect to each concentration was prepared by dissolving $1 \mathrm{~mL}$ DMSO in $5 \mathrm{~mL}$ malt extract broth and double diluted in series. Experiment was performed in glass test tubes $(10 \mathrm{~mL})$, each containing $1 \mathrm{~mL}$ of growth medium. Tubes were inoculated aseptically with $20 \mu \mathrm{L}$ of $M$. phaseolina suspension and each treatment was replicated three times. After 7 days of incubation at room temperature, fungal biomass was filtered, dried and weighed.

Isolation and purification of compounds. M. buxifolia lipophilic hexane fraction was subjected to vacuum liquid chromatography over silica gel and eluted with increasing order of solvent polarity as hexane-EtOAc $(0 \rightarrow 10)$. Hexane first sub-fraction, collected using $n$-hexane: EtOAc (7:3) was again chromatographed to isolate compound $1(10 \mathrm{mg})$ using same polarity system. Hexane second sub-fraction collected using $n$-hexane-EtOAc (6:4) was again chromatographed to isolate compound $2(8 \mathrm{mg})$ eluted with same solvent system. $\mathrm{CHCl}_{3}$ fraction was subjected to silica gel column and eluted with $n$-hexane-chloroform $(10: 0 \rightarrow 0: 0)$ to chloroform-methanol $(0: 0 \rightarrow 0: 10)$. Chloroform fraction lead to isolation of three main sub-fractions. $\mathrm{CHCl}_{3}$ sub-fraction 1 was further purified and compound 3 and $4(13,10 \mathrm{mg})$ were obtained with $n$-hexane- $\mathrm{CHCl}_{3}(7: 3) n$-hexane-dichloromethane (5:5) and (6:4) as eluent, respectively. Sub-fraction 2 eluted with $n$-hexane-chloroform (6:4) was purified with $n$-hexane:dichloromethane (5:5) to obtain compound 5 ( $15 \mathrm{mg}$ ). $\mathrm{CHCl}_{3}$ sub-fraction 3 eluted with chloroform-methanol (9.5:0.5) was rechromatographed using dichloromethane-methanol (9:1) to afford compound $6(30 \mathrm{mg})$. The EtOAc fraction was chromatographed using silica gel and eluted with solvent system of increasing polarity $n$-hexane, $n$-hexane: DCM and DCM:MeOH and three sub-fractions were collected. EtOAc sub-fraction 1, eluted by $n$-hexane: DCM (3:7) was refilled on silica gel and eluted by $n$-hexane:DCM (1:9) to attain compound $4(4 \mathrm{mg})$ and $7(6 \mathrm{mg})$. EtOAc sub-fraction 2 eluted by DCM 100\%, was reloaded and eluted by same solvent system to separate compound $8(8 \mathrm{mg})$. EtOAc sub-fraction 3 was isolated using DCM:MeOH (9:1) was rechromatographed and eluted with identical solvent system to collect compound 9 and $10(6,8 \mathrm{mg})$.

Physical properties, spectral analysis of pure compounds. Lupeol (1). Melting point, $215^{\circ} \mathrm{C}$ was recorded. ${ }^{1} \mathrm{H}-\mathrm{NMR}\left(400 \mathrm{MHz}, \mathrm{CD}_{3} \mathrm{OD}\right), \delta \mathrm{ppm}: 4.20$ and $4.21(2 \mathrm{H}$, br, $1 \mathrm{H}$ each, $\mathrm{H}-29), 3.30(1 \mathrm{H}, d d, J=9.4$, $4.6 \mathrm{~Hz}, \mathrm{H}-3), 0.74,0.81,0.85,0.89,0.91,0.97,1.06(3 \mathrm{H}, 7 \mathrm{~s}, 7 \mathrm{Me}) .{ }^{13} \mathrm{C}-\mathrm{NMR}(150 \mathrm{MHz}, \mathrm{CD} 3 \mathrm{OD}) \delta \mathrm{ppm}: 150.7$ (C-20), 109.7 (C-29), 79.2 (C-3), 55.2 (C-5), 50.3 (C-9), 48.3 (C-18), 47.8 (C-19), 43.2 (C-17), 42.7 (C-14), 40.7 (C-8), 39.9 (C-22), 38.6 (C-4), 38.2 (C-1), 38.0 (C-13), 37.3 (C-10), 35.9 (C-16), 35.0 (C-7), 29.7 (C-21), 28.4 (C-22), 28.2 (C-23)27.9 (C-2), 27.2 (C-15), 25.3 (C-12), 21.1 (C-11), 19.3 (C-30), 18.4 (C-6), 18.2(C-28), 15.8 (C-25), 15.5 (C-26), 15.3 (C-27), 15.1 (C-24). EI-MS $m / z[M]^{+}$at : 426.

Lupeol acetate (2). IR spectrum showed absorption at $1730 \mathrm{~cm}^{-1} \cdot{ }^{1} \mathrm{H}-\mathrm{NMR}\left(500 \mathrm{MHz}, \mathrm{CD}_{3} \mathrm{OD}\right), \delta \mathrm{ppm}: 4.47$ and $4.44(2 \mathrm{H}, \mathrm{br}, 1 \mathrm{H}$ each, $\mathrm{H}-29), 4.03(1 \mathrm{H}, d d, J=9.8,4.3 \mathrm{~Hz}, \mathrm{H}-3), 0.76,0.81,0.83,0.86,0.92,1.01,1.31(3 \mathrm{H}$, $7 \mathrm{~s}, 7 \mathrm{Me})$ and $2.32\left(3 \mathrm{H}, \mathrm{s}, \mathrm{CH}_{3} \mathrm{COO}\right) .{ }^{13} \mathrm{C}-\mathrm{NMR}\left(150 \mathrm{MHz}, \mathrm{CDCl}_{3}\right) \delta \mathrm{ppm}: 172.2\left(\mathrm{C}-1^{\prime}\right), 150.2(\mathrm{C}-20), 110.5$ (C-29), 81.1 (C-3), 50.7 (C-9), 48.7 (C-18), 48.4 (C-19), 38.5 (C-1), 22.7 (C-2), 37.2 (C-4), 55.3 (C-5), 18.3 (C-6), 34.8 (C-7), 41.2 (C-8), 40.1 (C-22), 37.2 (C-10), 21.2 (C-11), 24.6 (C-12), 37.2 (C-13), 43.0 (C-14), 26.4 (C-15), 35.8 (C-16), 43.1 (C-17), 29.9 (C-21), 28.2 (C-23), 20.4 (C-2'), 19.3 (C-30), 16.1 (C-24), 16.3 (C-25), 15.4 (C-26), 14.2 (C-27), $14.8(\mathrm{C}-28)$. EI-MS $m / z[\mathrm{M}]^{+}$at : 468. 
Betulin (3). Compound 3 showed IR spectrum at $3457 \mathrm{~cm}^{-1} .{ }^{1} \mathrm{H}-\mathrm{NMR}\left(500 \mathrm{MHz}, \mathrm{CDCl}_{3}\right), \delta \mathrm{ppm}: 4.46$ and $4.92(b r s, 1 \mathrm{H}$ each, $\mathrm{H}-29), 3.40$ and $3.71(2 \mathrm{H}, d, J=11.2 \mathrm{~Hz}, \mathrm{H}-28), 3.25(d d, J=11.4,5.2 \mathrm{~Hz}, \mathrm{H}-3), 0.83\left(\mathrm{H}_{3}-24\right)$, $0.84\left(\mathrm{H}_{3}-25\right), 0.86\left(\mathrm{H}_{3}-23\right), 0.87\left(\mathrm{H}_{3}-26\right), 1.02\left(\mathrm{H}_{3}-27\right), 1.04\left(\mathrm{H}_{3}-30\right)(3 \mathrm{H}, 6 \mathrm{~s}, 6 \mathrm{Me}) .{ }^{13} \mathrm{C}-\mathrm{NMR}(150 \mathrm{MHz}$, $\left.\mathrm{CDCl}_{3}\right) \delta$ ppm: 150.8 (C-20), 109.8 (C-29), 79.1 (C-3), 60.4 (C-28), 38.4 (C-1), 55.3 (C-5), 50.6 (C-9), 48.6 (C-19), 46.6 (C-17), 42.5 (C-18), 42.8 (C-14), 27.5 (C-2), 39.2 (C-4), 37.5 (C-13), 36.2 (C-22), 30.2 (C-21), 18.4 (C-6), 34.3 (C-7), 39.5 (C-8), 37.2 (C-10), 21.0 (C-11), 24.2 (C- 12), 27.2 (C-15), 30.3 (C-16), 28.1 (C-23), 19.1 (C-30), 16.1 (C-25), 16.2 (C-26), 15.2 (C-24), $14.8(\mathrm{C}-27)$. EI-MS $m / z[\mathrm{M}]^{+}$at : 442.

$\beta$-sitosterol (4). ${ }^{1} \mathrm{H}-\mathrm{NMR}\left(500 \mathrm{MHz}, \mathrm{CDCl}_{3}\right), \delta \mathrm{ppm}: 5.41(1 \mathrm{H}, t, J=3.2 \mathrm{~Hz}, \mathrm{H}-6), 3.45(1 \mathrm{H}, m, \mathrm{H}-3), 1.034(3 \mathrm{H}$, $s, \mathrm{Me}-19), 0.902(3 \mathrm{H}, d, J=6.4, \mathrm{Me}-21), 0.89(3 \mathrm{H}, d, J=6.8, \mathrm{Me}-29), 0.86(3 \mathrm{H}, d, J=6.6, \mathrm{Me}-26), 0.82(3 \mathrm{H}, d, J=6.6$, Me-27), 0.68 (3H,s, Me-18). ${ }^{13} \mathrm{C}-\mathrm{NMR}\left(150 \mathrm{MHz}, \mathrm{CDCl}_{3}\right) \delta \mathrm{ppm:} 141.2$ (C-5), 122.1 (C-6), $72.2(\mathrm{C}-3), 56.8$ (C-14), 56.2 (C-17), 51.9 (C-9), 46.4 (C-24), 42.4 (C-4), 41.8 (C-13), 40.6 (C-12), 36.8 (C-1), 35.8 (C-10), 34.4 (C-20), 32.2 (C-22), 31.8 (C-7), 31.6 (C-8), 31.2 (C-2), 30.4 (C-25), 28.6 (C-16), 25.4 (C-23); 24.8 (C-15), 23.8 (C-28), 22.8 (C-11), 21.2 (C-26), 20.6 (C-19), 19.8 (C-27), 18.9 (C-21), 12.8 (C-29), 12.6 (C-18). EI-MS $m / z[M]^{+}$ at : 414 .

$\beta$-amyrin (5). Absence of absorption in UV region was indicated. ${ }^{1} \mathrm{H}-\mathrm{NMR}\left(500 \mathrm{MHz}, \mathrm{CD}_{3} \mathrm{OD}\right), \delta$ ppm: 5.22 $(1 \mathrm{H}, b r s, \mathrm{H}-12), 3.61(1 \mathrm{H}, d d, J=8,4.4 \mathrm{~Hz}, \mathrm{H}-3), 0.80(3 \mathrm{H}, s), 0.84(3 \mathrm{H}, s), 0.88(3 \mathrm{H}, s), 0.95(3 \mathrm{H}, s), 1.12(3 \mathrm{H}$, s), $1.34(3 \mathrm{H}, s), 1.01(3 \mathrm{H}, s)$ and $1.11(3 \mathrm{H}, s) .{ }^{13} \mathrm{C}-\mathrm{NMR}\left(150 \mathrm{MHz}, \mathrm{CDCl}_{3}\right) \delta \mathrm{ppm}: 145.6(\mathrm{C}-13), 121.4(\mathrm{C}-12)$, 78.8 (C-3), 47.2 (C-18), 46.6 (C-19), 37.8 (C-1), 28.1 (C-2), 38.4 (C-4), 55.6 (C-5), 18.8 (C-6), 33.1 (C-7), 38.2 (C-8), 47.8 (C-9), 37.2 (C-10), 23.4 (C-11), 41.2 (C-14), 26.8 (C-15), 27.3 (C-16), 32.2 (C-17), 31.1 (C-20); 34.2 (C-21), 37.3 (C-22), 28.9 (C-23), 15.5 (C-24), 15.6 (C-25), 16.7 (C-26), 26.4 (C-27), 28.8 (C-28), 33.4 (C-29), 23.8 (C-30). EI-MS $m / z[\mathrm{M}]^{+}$at : 426 .

Oleanolic acid (6). IR spectrum showed absorption band 3430-2650, 1680 and 1650-850 $\mathrm{cm}^{-}$respectively. ${ }^{1} \mathrm{H}-$ $\operatorname{NMR}\left(500 \mathrm{MHz}, \mathrm{CDCl}_{3}\right), \delta \mathrm{ppm}: 5.18(1 \mathrm{H}, b r s, \mathrm{H}-12), 3.14(1 \mathrm{H}, d d, J=10,5.5 \mathrm{~Hz}, \mathrm{H}-3), 1.19(3 \mathrm{H}, s), 1.02(3 \mathrm{H}$, $s), 0.92(3 \mathrm{H}, s), 0.88(3 \mathrm{H}, s), 0.80(3 \mathrm{H}, s), 0.74(3 \mathrm{H}, s)$ and $0.71(3 \mathrm{H}, s) .{ }^{13} \mathrm{C}-\mathrm{NMR}\left(150 \mathrm{MHz}, \mathrm{CDCl}_{3}\right) \delta$ ppm: 180.8 (C-28), 145.8 (C-13), 124.4 (C-12), 78.2 (C-3), 55.9 (C-5), 48.5 (C-9), 47.2 (C-17), 46.6 (C-19), 42.5 (C-18), 42.4 (C-14), 39.4 (C-4), 38.8 (C-1), 33.8 (C-29), 33.3 (C-7), 40.1 (C-8), 37.1 (C-10), 31.4 (C-20); 34.8 (C-21), 33.1 (C-22), 29.8 (C-23), 24.1 (C-11), 28.8 (C-15), 28.2 (C-2), 26.8 (C-27), 24.2 (C-16), 23.6 (C-30), 19.1 (C-6), 17.2 (C-26), $16.4(\mathrm{C}-24), 16.1(\mathrm{C}-25)$. EI-MS $m / z[\mathrm{M}]^{+}$at : 456.

Vanillic acid (7). The UV $\lambda_{\max }$ showed absorption at $282 \mathrm{~nm}$. The infrared spectrum displayed absorption bands at $3400-2700$ and $1670 \mathrm{~cm}^{-1}$ indicated the presence of conjugated carboxylic acid. ${ }^{1} \mathrm{H}-\mathrm{NMR}(500 \mathrm{MHz}$, $\left.\mathrm{CD}_{3} \mathrm{OD}\right), \delta$ ppm: $7.60(1 \mathrm{H}, d, 1.6 \mathrm{~Hz}, \mathrm{H}-2), 7.55(1 \mathrm{H}, d d, J=8.2,1.6 \mathrm{~Hz}, \mathrm{H}-6), 6.80(1 \mathrm{H}, d, J=8.2, \mathrm{H}-5), 4.59$ $(1 \mathrm{H}, s, \mathrm{OH}), 3.88\left(3 \mathrm{H}, s, \mathrm{OCH}_{3}\right) .{ }^{13} \mathrm{C}-\mathrm{NMR}\left(150 \mathrm{MHz}, \mathrm{CD}_{3} \mathrm{OD}\right) \delta \mathrm{ppm}: 55.9\left(\mathrm{CH}_{3} \mathrm{O}-3\right), 112.3(\mathrm{C}-2), 114.3(\mathrm{C}-5)$, 121.9 (C-6), 124.0 (C-1), $146.6(\mathrm{C}-3), 150.5(\mathrm{C}-4)$. EI-MS $m / z[\mathrm{M}]^{+}$at : 168.

Protocatechuic acid (8). UV absorption was recorded at $274 \mathrm{~nm}$, IR spectrum displayed absorption bands at $3210-2610 \mathrm{~cm}^{-1} .{ }^{1} \mathrm{H}-\mathrm{NMR}\left(500 \mathrm{MHz}, \mathrm{CD}_{3} \mathrm{OD}\right), \delta \mathrm{ppm}: 7.45(1 \mathrm{H}, d d, J=8.2,1.8 \mathrm{~Hz}, \mathrm{H}-6), 7.42(1 \mathrm{H}, d, J=1.8 \mathrm{~Hz}$, $\mathrm{H}-2), 6.82(1 \mathrm{H}, d, J=8.2 \mathrm{~Hz}, \mathrm{H}-5),{ }^{13} \mathrm{C}-\mathrm{NMR}\left(150 \mathrm{MHz}, \mathrm{CDCl}_{3}\right) \delta \mathrm{ppm}: 123.4(\mathrm{C}-1), 120.9$ (C-2), $147.2(\mathrm{C}-3)$, 148.9 (C-4), 117.4 (C-5), 118.5 (C-6), 170.5 (C-7). EI-MS $m / z[\mathrm{M}]^{+}$at : 154.

Kaempferol (9). Melting point at $276-278{ }^{\circ} \mathrm{C}$ was recorded. UV spectrum recorded $\lambda_{\max }$ at 265,212 and 336 (4.0) $\mathrm{nm}$ while IR spectrum showed absorption at 3412, 2926, 1660, 1610, 1600-1525 and $1380 \mathrm{~cm}^{-1}$. ${ }^{1} \mathrm{H}-\mathrm{NMR}$ (400 MHz, DMSO), $\delta$ ppm: $8.03\left(2 \mathrm{H}, d, J=8.8 \mathrm{~Hz}, \mathrm{H}-2^{\prime},-6^{\prime}\right), 6.92\left(2 \mathrm{H}, d, J=8.8 \mathrm{~Hz}, \mathrm{H}-3^{\prime},-5^{\prime}\right), 6.42(1 \mathrm{H}, d$, $J=1.8 \mathrm{~Hz}, \mathrm{H}-8), 6.18(1 \mathrm{H}, d, J=1.8 \mathrm{~Hz}, \mathrm{H}-6) \cdot{ }^{13} \mathrm{C}-\mathrm{NMR}(150 \mathrm{MHz}, \mathrm{CD} 3 \mathrm{OD}) \delta \mathrm{ppm}: 178.1(\mathrm{C}-4), 161.4(\mathrm{C}-5)$, 160.2 (C-7), 159.4 (C-4'), 155.9 (C-9), 146.2 (C-2), 137.2 (C-3), 128.3 (C-2', -6'), $121.3\left(\mathrm{C}-1^{\prime}\right), 114.2\left(\mathrm{C}-3^{\prime},-5^{\prime}\right)$, 103.4 (C-10), 99.8 (C-6), $93.4(\mathrm{C}-8)$. EI-MS $m / z[\mathrm{M}]^{+}$at : 286.

Quercetin (10). Melting point was recorded at $314-316^{\circ} \mathrm{C}$. Two characteristic absorption bands in UV spectrum at 250 and $360 \mathrm{~nm}$ were showed. HR-EI-MS spectra depicted molecular ion peak at $\mathrm{m} / z 302.0285$ with relevant molecular formula $\mathrm{C}_{15} \mathrm{H}_{10} \mathrm{O}_{6}$. IR spectrum showed two characteristic bands at 3402 and $1610 \mathrm{~cm}^{-1}$. ${ }^{1} \mathrm{H}-\mathrm{NMR}\left(300 \mathrm{MHz}, \mathrm{CD}_{3} \mathrm{OD}\right), \delta$ ppm: $7.72\left(1 \mathrm{H}, d, 2.1 \mathrm{~Hz}, \mathrm{H}-2^{\prime}\right), 7.62\left(1 \mathrm{H}, d d, J=8.4,2.1 \mathrm{~Hz}, \mathrm{H}-6^{\prime}\right), 6.87(1 \mathrm{H}$, $\left.d, J=8.4, \mathrm{H}-5^{\prime}\right), 6.38(1 \mathrm{H}, d, J=1.8, \mathrm{H}-8), 6.17(1 \mathrm{H}, d, J=1.8, \mathrm{H}-6) .{ }^{13} \mathrm{C}-\mathrm{NMR}(150 \mathrm{MHz}, \mathrm{CD} 3 \mathrm{OD}) \delta$ ppm: 170.5 (C-4), 165.1 (C-7), 160.9 (C-5), 160.0 (C-9), 150.8 (C-4'), 146.4 (C-3'), 146.2 (C-2), $137.1(\mathrm{C}-3), 124.2\left(\mathrm{C}-1^{\prime}\right)$, $121.4\left(\mathrm{C}-6^{\prime}\right) 117.0\left(\mathrm{C}-2^{\prime},-5^{\prime}\right), 104.2(\mathrm{C}-10), 99.2(\mathrm{C}-6), 94.1(\mathrm{C}-8)$. EI-MS $m / z[\mathrm{M}]^{+}$at : 302.

Antifungal bioassays with pure compounds from $\boldsymbol{M}$. buxifolia. Two compounds $(1,2)$ were isolated from $n$-hexane fraction, four compounds (3-6) from chloroform fraction and four compounds (7-10) from ethyl acetate fraction of the methanolic extract of $M$. buxifolia were tested for MIC values by microdilution assay. MIC values of mancozeb as reference synthetic fungicide ( $80 \% \mathrm{WP}, \mathrm{KSS})$ and isolated compounds were tested by serial dilution in culture tubes. Six milligrams of each of the ten isolated compounds and mancozeb (active ingredient) were dissolved in $20 \mu \mathrm{L}$ DMSO and added to autoclaved malt extract to raise the volume up to $3 \mathrm{~mL}$, to prepare a growth medium of $2 \mathrm{mg} \mathrm{mL}^{-1}$ concentration. Further serial double dilutions viz. 1, 0.5, $0.25 \ldots 0.0312 \mathrm{mg} \mathrm{mL}^{-1}$ were made using malt extract broth in culture tubes. Spore suspension was prepared by adding 10 day old fungal culture in double distilled water. DMSO $(20 \mu \mathrm{L} \mathrm{mL})$ was added in malt extract broth 
to prepare $3 \mathrm{~mL}$ of control that serially double diluted to make corresponding control treatments for each concentration. Each treatment was replicated thrice. Fugal suspension $(20 \mu \mathrm{L})$ was added to each concentration $(0.5 \mathrm{~mL})$ of the growth medium and incubated at $27^{\circ} \mathrm{C}$. Fungal biomass was collected on filter papers after 3 days growth, dried and weighed.

Statistical analysis. All the data were analyzed by analysis of variance followed by Tukey's HSD Test using computer software Statistix 8.1.

Ethics approval. This article does not contain any studies with human participants or animal experiments.

Received: 15 December 2020; Accepted: 1 April 2021

Published online: 19 April 2021

\section{References}

1. Shifa, H., Gopalakrishnan, C. \& Velazhahan, R. Management of late leaf spot (Phaeoisariopsis personata) and root rot (Macrophomina phaseolina) diseases of groundnut (Arachis hypogaea L.) with plant growth promoting rhizobacteria, systemic acquired resistance inducers and plant extracts. Phytopara 46, 19-30 (2018).

2. Awla, H. K., Kadir, J., Othman, R., Rashida, T. S., Hamid, S., \& Wonga, M. Y. Plant growth-promoting abilities and biocontrol efficacy of Streptomyces sp. UPMRS4 against Pyricularia oryzae. Biol. Control 112, 55-63 (2017).

3. Javaid, A., Latif, U., Akhtar, N., Ahmed, D. \& Perveen, S. Molecular characterization of Fusariummoniliforme and its management by methanolic extract of Coronopusdidymus. Pak. J. Bot. 50, 2069-2075 (2018).

4. Javaid, A., Shahzad, G. R., Akhtar, N. \& Ahmed, D. Alternaria leaf spot disease of broccoli in Pakistan and management of the pathogen by leaf extract of Syzygiumcumini. Pak. J. Bot. 50, 1607-1614 (2018).

5. Khurshid, S., Javaid, A., Shoaib, A., Javed, S. \& Qaiser, U. Antifungal activity and GC-MS analysis of aerial parts of Cenchrus pennisetiformis against Fusarium oxysporum f. sp. lycopersici. Plan Danin 36, e017166627 (2018).

6. Javaid, A. \& Amin, M. Antifungal activity of methanol and $n$-hexane extracts of three Chenopodium species against Macrophominaphaseolina. Nat. Prod. Res. 23, 1120-1127 (2009).

7. Banaras, S., Javaid, A., Shoaib, A. \& Ahmed, E. Antifungal activity of Cirsiumarvense extracts against a phytopathogenic fungus Macrophominaphaseolina. Plan Danin. 35, e017162738 (2017).

8. Javaid, A., Qudsia, H. \& Shoaib, A. Bioassays guided fractionation of Sennaoccidentalis for identification of natural antifungal constituents against Macrophominaphaseolina. Plan Danin. 35, e017163483 (2017).

9. Javaid, A., Afzal, L. \& Shoaib, A. Biological control of charcoal rot of mungbean by Trichodermaharzianum and shoot dry biomass of Sisymbriumirio. Plan Danin. 35, e017165756 (2017).

10. Javaid, A., Khan, I. H. \& Shoaib, A. Management of charcoal rot of mungbean by two Trichoderma species and dry biomass of Coronopusdidymus. Plan Danin. 36, e018182795 (2018).

11. Kanwal, Q., Hussain, I., Siddiqui, H. L. \& Javaid, A. Antimicrobial activity screening of isolated flavonoids from Azadirachtaindica leaves. J. Serb. Chem. Soc. 76, 375-384 (2011).

12. Kanwal, Q., Hussain, I., Siddiqui, H. L. \& Javaid, A. Antifungal activity of flavonoids isolated from mango (Mangifera indica L.) leaves. Nat. Prod. Res. 24, 1907-1914 (2010).

13. Hassan, S. et al. In vivo pharmacological investigation of Monothecabuxifolia and Boseaamherstiana using animal models. Saudi J. Biol. Sci. 26, 1602-1606 (2018).

14. Fayaz, A. et al. Efficacy of different solvent extracts from selected medicinal plants for the potential of antibacterial activity. Pure Appl. Biol. 7, 890-896 (2018).

15. Javed, S. et al. Isolation, identification and anti proliferative activity of triterpenes from the Genus Monotheca A. DC.. Rec. Nat. Prod. 10, 782-787 (2016).

16. Shakala, B., Buthalpali, K., Dantu, K. S., Buchiaraju, R. \& Sreekanth, N. An evaluation of the antibacterial activity of root extracts of ManilkaraZapota against Staphylococcusaureus and Escherichiacoli. Int. J. Phytopharm. 4, 171-173 (2013).

17. Uddin, G. \& Rauf, A. Phytochemical screening and biological activity of the aerial parts of Elaeagnusumbellate. Sci. Res. Essays 7, 3690-3694 (2012).

18. Wyllie, T. D. Charcoal rot. In (Sinclair J. B., Backman P. A. eds) Compendium of Soybean Diseases Vol. 3, 30-33 (APS Press, 1993).

19. Blair, J. A., Ongley, P. A., Chiswell, J. \& Griffiths, M. H. G. The isolation of lupeol from the bark of Heritierautilis(Tarrietiautilis). Phytochemistry 9,671 (1970).

20. Appleton, R. A. \& Enzell, C. R. Triterpenoids and aromatic components of deertongue leaf. Phytochemistry 10, 447-449 (1971).

21. Wu, Y., Zhang, J., Wang, D., Liu, J. \& Hu, Y. Triterpenoid Saponins from Ziziphus jujuba var. spinose. Chem. Nat. Comp. 49, 677-681 (2013).

22. Aydina, T. et al. Insecticidal metabolites from the rhizomes of Veratrumalbum against adults of Colorado potato beetle, Leptinotarsadecemlineata. Chem. Biodivers. 11, 1192-1204 (2014).

23. Catharina, E. et al. Triterpene esters: natural products from Dorsteniaarifolia (Moraceae). Molecules 18, 4247-4256 (2013).

24. Liao, C. R. et al. Studies on cytotoxic constituents from the leaves of Elaeagnusoldhamii Maxim in non-small cell lung cancer A-549 cells. Molecules 19, 9515-9534 (2014).

25. Azizuddin, M. T. \& Choudhary, M. I. Radical scavenging potential of compounds isolated from Vitexagnus-castus. Turk. J. Chem. 34, 119-126 (2010).

26. Al-Musayeib, N., Perveen, S., Fatima, I., Nasir, M. \& Hussain, A. Antioxidant, anti-glycation and anti-inflammatory activities of phenolic constituents from Cordiasinensis. Molecules 12, 10214-10226 (2011).

27. Gao, L., Xu, X. \& Yang, J. Chemical constitutes of the roots of Rheumofficinale. Chem. Nat. Comp. 49, 603-605 (2013).

28. Ding, C., Zhang, W., Li, J., Lei, J. \& Yu, J. Cytotoxic constituents of ethyl acetate fraction from Dianthussuperbus. Nat. Prod. Res. 27, 1691-1694 (2013).

29. Awolola, G. V., Koorbanally, N. A., Chenia, H., Shode, F. O. \& Baijnath, H. Antibacterial and anti-biofilm activity of flavonoids and triterpenes isolated from the extracts of Ficus Sansibarica Warb. subsp. sansibarica (Moraceae) extracts. Afr. J. Tradit. Complement. Altern. Med. 11, 124-131 (2014).

30. Muktar, B., Bello, I. A. \& Sallau, M. S. Isolation, characterization and antimicrobial study of lupeol acetate from the root bark of fig-mulberry sycamore (Ficussycomorus Linn). J. Appl. Sci. Environ. Manag. 22, 1129-1133 (2018).

31. Manzano, P. I. et al. Pentacyclic triterpenoids with antimicrobial activity from the leaves of Vernonanthurapatens (Asteraceae). Emir. J. Food Agric. 25, 539-543 (2013).

32. Nisar, M. et al. Antifungal activity of bioactive constituents and bark extracts of Rhododendronarboreum. Bang. J. Pharm. 8, 218-222 (2013). 
33. Ogwuche, C. E., Amupitan, J. O., Ndukwe, I. G. \& Ayo, R. G. Isolation and Biological Activity of the triterpene B-amyrin from the aerial plant parts of Maesobotryabarteri (Baill). Med. Chem. 4, 11 (2014).

34. Jabeen, K., Javaid, A., Ahmad, E. \& Athar, M. Antifungal compounds from Meliaazederach leaves for management of Ascochytarabiei, the cause of chickpea blight. Nat. Prod. Res. 25, 264-276 (2011).

35. Favel, A. et al. Invitro antifungal activity of triterpenoid saponins. Plan Med. 60, 50-53 (1994).

36. Jesus, J. A., Lago, J. H. G., Laurenti, M. D., Yamamoto, E. S. \& Passero, L. F. D. Antimicrobial activity of oleanolic and ursolic acids: An update. Evid. Based Complement. Altern. Med. 2015, 620472 (2015).

37. Semaming, Y., Pannengpetch, P., Chattipakorn, S. C. \& Chattipakorn, N. Pharmacological properties of protocatechuic acid and its potential roles as complementary medicine. Evid. Based Complement. Altern. Med. 2015, 593902 (2015).

38. Kuete, V., Tangmouo, J. G., Penlap, V. P., Ngounou, F. N. \& Lontsi, D. Antimicrobial activity of the methanolic extract from the stem bark of Tridesmostemonomphalocarpoides (Sapotaceae). J. Ethnopharma. 104, 5-11 (2006).

39. Wal, A., Srivastava, R. S., Wal, P., Rai, A. \& Sharma, S. Lupeol as a magical drug. Pharmaceut. Biol. Evaluat. 2, 142-151 (2015).

40. Singh, B. \& Singh, S. Antimicrobial activity of terpenoids from from Trichodermaamplexicaule Roth. Phytother. Res. 17, 814-816 (2003).

41. Lall, N., Weiganand, O., Hussein, A. A. \& Meyer, J. J. M. M. Antifungal activity of naphthoquinones and triterpenes isolated from the root bark of Eucleanatalensis. S. Afr. J. Bot. 72, 579-583 (2006).

42. Alves, C. T. et al. Antifungal activity of phenolic compounds identified in flowers from North Eastern Portugal against Candida species. Future Microbiol. 9, 139-146 (2014).

43. Oliveira, V. M., Carraroa, E., Aulerb, M. A. \& Khalilc, N. M. Quercetin and rutin as potential agents antifungal against Cryptococcus spp.. Braz. J. Biol. 76, 1029-1034 (2016).

44. Del, V. P. et al. Antimicrobial activity of kaempferol and resveratrol in binary combinations with parabens or propyl gallate against Enterococcusfaecalis. Food Control 61, 213-220 (2016).

\section{Acknowledgements}

University of the Punjab, Lahore, Pakistan is thanked for providing research grant to work with Medicinal Chemistry and Natural Products Research Group in School of Pharmacy and Biomolecular Sciences, Liverpool John Moores University, England.

\section{Author contributions}

S.J. Performed experiments, analysed data and wrote first draft of the manuscript; Z.M. Designed experiment; K.M.K. contributed in supervising chromatographic isolation and characterization of compounds; S.D.S. Contributed in compounds isolation and identification A.J. Designed, supervised and wrote experiments relevant to antifungal assays; I.H.K. Performed antifungal bioassays; A.S. Supervised antifunal assays and revised manuscript. All authors have substantial contributions to the final manuscript and approved this submission.

\section{Competing interests}

The authors declare no competing interests.

\section{Additional information}

Correspondence and requests for materials should be addressed to A.S.

Reprints and permissions information is available at www.nature.com/reprints.

Publisher's note Springer Nature remains neutral with regard to jurisdictional claims in published maps and institutional affiliations.

(c) (i) Open Access This article is licensed under a Creative Commons Attribution 4.0 International License, which permits use, sharing, adaptation, distribution and reproduction in any medium or format, as long as you give appropriate credit to the original author(s) and the source, provide a link to the Creative Commons licence, and indicate if changes were made. The images or other third party material in this article are included in the article's Creative Commons licence, unless indicated otherwise in a credit line to the material. If material is not included in the article's Creative Commons licence and your intended use is not permitted by statutory regulation or exceeds the permitted use, you will need to obtain permission directly from the copyright holder. To view a copy of this licence, visit http://creativecommons.org/licenses/by/4.0/.

(c) The Author(s) 2021 